Article

\title{
How Sustainable Social Media Advertising Affect Visitors' Decision to Attend a Festival Event?
}

\author{
Luyi Qiu ${ }^{1,2}$, Aro I ${ }^{3}$, Timothy J. Lee ${ }^{4,5, *}$ and Jinok Susanna Kim ${ }^{6}$ \\ 1 Department of International Trade and Economics, Ningbo Polytechnic, Ningbo 315800, China; \\ 0000036@nbpt.edu.cn \\ 2 Business School, Universiti Kuala Lumpur (UniKL), Kuala Lumpur 50250, Malaysia \\ 3 Faculty of Arts and Social Sciences, University of Surrey, Guildford GU2 7XH, UK; mangoholic46@naver.com \\ 4 Faculty of Hospitality and Tourism Management, Macau University of Science and Technology (MUST), \\ Macao 999078, China \\ 5 Griffith Institute for Tourism (GIFT), Griffith University, Nathan, QLD 4111, Australia \\ 6 Department of Airline Service, Sehan University, Dangjin 31746, Korea; s2924@sehan.ac.kr \\ * Correspondence: tjlee@must.edu.mo; Tel.: +853-8897-2386
}

Citation: Qiu, L.; I, A.; Lee, T.J.; Kim, J.S. How Sustainable Social Media Advertising Affect Visitors' Decision to Attend a Festival Event? Sustainability 2021, 13, 9710. https://doi.org/10.3390/su13179710

Academic Editor: Yoonjae Nam

Received: 7 June 2021

Accepted: 17 August 2021

Published: 30 August 2021

Publisher's Note: MDPI stays neutral with regard to jurisdictional claims in published maps and institutional affiliations.

Copyright: (c) 2021 by the authors. Licensee MDPI, Basel, Switzerland. This article is an open access article distributed under the terms and conditions of the Creative Commons Attribution (CC BY) license (https:// creativecommons.org/licenses/by/ $4.0 /)$.

\begin{abstract}
This research aims to investigate the possibilities of event visitors being persuaded to purchase tickets by music festival advertising on social media. Music festival and social media in general were chosen to be analyzed in two major areas: advertising formats and persuasion. Moreover, general perception towards music festival advertising on social media and the relationship between social media advertising with tactics were examined. The main objective of this research was to investigate the relationship between the use of social media advertising and the purchase of music festival tickets. To investigate the analysis of how consumers perceived music festival advertising on social media and the possibilities of being persuaded to purchase the festival ticket, a quantitative offline questionnaire method was adopted and applied. It was identified that general perception toward music festival advertising on social media is positive. Furthermore, it was found that being persuaded by social media advertisement to purchase music festival ticket is positive as well. The findings of this study concluded that consumers might be persuaded to purchase the music festival ticket although different conditions were applied to the social media advertising.
\end{abstract}

Keywords: music festival; sustainable event; advertising; decision-making

\section{Introduction}

Festivals or special events have been regarded as one of the fastest developing industries within the tourism industry [1]. Festivals have considerably contributed to bringing people together thus enhancing the general quality of life for festival goers [2]. Festivals in general, and music festivals specifically, are growing recognition for improving a region's image and appeal, developing recreational possibilities, contributing to local economies and enhancing local culture and pride [3]. According to new definition of marketing, there is a focus on creating and delivering value through customer relationships permeates over creating satisfactory exchanges [4]. After the Internet was invented, Internet marketing has become a significant contributor for companies and brands to meet their marketing objectives. Digital marketing has supported organizations to extend into new markets, offer new services and interact with consumers in new ways in which contend on a more equal footing with larger businesses [5]. New web technology has developed a simpler way for anyone to create their own content [6] and marketers and advertisers have taken advantage of that to reimburse successful content creators a great amount of money to embed their messages into their social media content [7].

The phenomenon of social media and its growth has greatly expanded all over the world. It has permanently changed the ways innumerable consumers interact with each 
other and organizations [8]. Social media is being used widely by almost every business, regardless of the size of the company. It is common practice now to use social media to advertise and promote their companies and products [6]. It is crucial to understand the significance of the role of social media in the context of marketing for both researchers and managers $[9,10]$.

In order to get full advantages of using event marketing, organizations need to consider whom they are targeting [11]. Events targeting customers and other organizations, need to be highly interactive and engaging, depending on the kind of event [12]. Few researchers have examined the promotion or marketing of music events, although Duarte et al. [13] found that organizers of music festivals in Spain do not aggressively promote their festivals from a touristic point of view, instead relying on positive word of mouth to build a loyal following. Hudson and Thal [14] argue that social networks are major delivery channels for festivals and organizers which allow them to provide a large amount of information regarded festival such as general festival information and artist information. With the rapid growth of social media as a means of marketing and the boom in the number of festivals across the world, this study serves to explore how social media advertising can influence and persuade customers to buy tickets to festivals.

The parameters of this study are focused on the younger generation (18-24) attending music festivals in general and having event marketing channel with social media. Social media has become an indispensable passage for global marketing communications and is commanding a greater share of advertising budgets, particularly to succeed in the younger generation. Therefore, managers, companies and scholars are interested in the value of advertising on social media like Twitter, Youtube, Facebook, LinkedIn and others [15]. Nevertheless, organizations and managers are particularly interested in the social media usage from Millennials since it may provide an indication of how these consumers will behave in the future, as well as what their perceptions are towards their brands [16].

A recent example how much social media can influence ticket sales is demonstrated in the recent case of the Fyre Festival. Billy McFarland, a tech entrepreneur and his business partner, rapper Ja Rule, decided to have an exclusive, high end music festival on a Bahamian island to promote his Fyre Media. In their promotional video, it was emphasizing "the luxurious experience on a Bahamian island for two weeks". In order to notify the festival and to boost ticket sales, McFarland used 400 influencers on Instagram for an influencer marketing strategy. With lots of famous celebrities posting about the event, Fyre attained the interest of 300 million people in $48 \mathrm{~h}$ and sold out all tickets [17]. However, upon the actual festival, attendees found that the whole promotional video was false; transportation, accommodation, music artists and food were completely opposed from what they had advertised. Nowadays, the case of Fyre Festival has become a marketing case study of what not to do [17].

The findings of these study will give some insights on how professionals in the events industry might want to use social media advertising to drive ticket sales to music festivals and the identify the types of content that more sustainably persuades customers to buy tickets [18]. Although there is a plethora of studies of the global event industry and on the impact of social media on event tourism, many of these are focused on word of mouth, efficient operation or cost savings. In fact, research on the role of social media in actual visitor decision making to attend a music festival is still scarce. The current study fills the gap in this area of research. This study may also encourage further research into the significant impact on different types of special events such as business events, themed events, and different kinds of festivals. Consequently, the current study aims to investigate the following question: "In which ways can social media advertisements of music festival persuade customers to purchase tickets?" The research objectives are (a) To investigate the relationship between the use of social media advertising and the purchase of music festival tickets, (b) To examine the impact of social media advertising contents to persuade customers to purchase music festival tickets, and (c) To draw conclusions 
on how significantly social media advertisements persuade customers to purchase music festival tickets.

The next section begins with discussion on the relevant key literature related to the topic: (i) Music festival marketing in social media for the sustainable event, (ii) Social media marketing, and (iii) Consumer behavior and motivations. Then, the paper illustrates the research philosophy and approach that applied to this study. It generates hypotheses and creates a research strategy. It presents the process of data collection and data analysis. It, then, discusses key findings from the data analysis with interpreted research results. Finally, the paper concludes by summarizing significant theoretical contributions, managerial implications, as well as the limitation and recommendations for further research.

\section{Literature Review}

\subsection{Music Festival Marketing on Social Media for a Sustainable Event}

\subsubsection{Understanding the Music Festival Industry}

Festivals play a significant role in the industry of tourism [19], as they not only attract visitors, but also build images for the destinations [20] and influence the economy and market of local communities [7]. It is crucial for festival organizers to understand festival attendees' experience, in order to predict their future buying behavior [21]. Strengthening the consumers' memories of their participation to the event, is the best way for a business to generate a satisfactory experience [19]. Nowadays, musical festival has become common in most countries, regions and cities with varieties of genre such as classical, rock and jazz music festival. Yoo, Lee and Lee [22] found that there is more demand for festivals because of an increasing availability of time for leisure and holidays; besides this, there is an increasing demand for cultural celebration as well. It was reported from Live Nation-one of the largest festivals and live music events organizations in Europe-that, during the financial crisis in 2008, no slowdown had been registered in their business [23].

Getz [24] also argued that private profit or fund-raising can be different business reasons for the growth of music festivals, in addition to leisure time, interests and sociodemographic factors, which also contribute as another reason behind the growth of the music festival industry. There are different schools of thought in the existing literature when discussing the definition of music festival marketing. Festival organizers, in particular cultural organizations, face numerous issues such as competition, globalization, development of new technologies and succession [23], which makes marketing essential for the success of the festival. Moreover, cultural and artistic organizations differ from other types of businesses: the former are more customer focused, whereas the customer experience is less significant for the latter, which frequently prioritize commercial purposes [25].

\subsubsection{Types of Music Festival Marketing}

The organization of a music festival involves a great number of requirements, fees for insurance, licensing, security and a variety of different equipment and technologies. In order to cover all the costs involved, festival organizers have turned to commercial and media sponsorships which can provide funding, for example, by underwriting to support productions fees or by issuing a one-off payment [26]. A sponsor usually contributes also by supplying co-promotions and advertising prior to the festival, thus aiming to raise awareness and interest amongst a specific target audience. This technique is expected to lead to early-bird ticket sales, and reduce the receipts issued at the gates on the event date. Event sponsors have developed their strategies focusing on experiential marketing in order to avoid criticisms of exploitative sponsorship activities [26]. Lanier and Hampton [27] suggest that "the strategy of creating and staging offerings for the purpose of facilitating memorable customer experiences" (2009, p. 10) will certainly affect brand perception. These strategies are applied to music festivals, too.

Word of mouth (WOM) is a way to communicate that spontaneously starts from independent actors and, as such, is supposedly regarded as more credible and worth of trust. This is enough to make it a powerful influential factor that impact decision making 
and brand loyalty [28]. With regard to online marketing, it has now become increasingly common in the festival scene to sell so called "early-bird" tickets on sale well in advance and at a discounted rate, as well as to make available for purchase a number of tickets for future events soon after the end of the current year's one [26].

Keller [29] (p. 141) defines advertising as "any paid form of non-personal presentation and promotion of ideas, goods or services by an identified sponsor". In recent years it is easily noticed that the media environment has changed dramatically. Traditional advertising media such as newspapers, radio, TV and magazines are losing their consumers [29]. The development of technology and new media have profoundly changed the process of consumers' communications. The speedy diffusion of influential broadband Internet connections, ad-skipping digital video recorders, multi-purpose mobile phones and portable music and video players have enforced marketers to reconsider a number of their traditional practices [30].

\subsection{Social Media Marketing}

The definition of social media has been diversified in a variety of ways. Kaplan and Haenlein [31] (p. 61) define them as "a group of Internet-based applications that build on the ideological and technological foundations of Web 2.0 and allow the creation and exchange of User Generated Content" [32] (p. 72). Andzulis, Panagopoulous and Rapp [33] (p. 208) define them as "the technological component of the communication, transaction and relationship building functions of a business". Furthermore, social media refer to highly interactive platforms via which individuals and communities share, discuss and revise user generated content [34].

Kaplan and Haenlein [31] claim that a formal definition of the social media term requires a relationship between two related concepts that are frequently named as Web 2.0 and User Generated Content. Web 2.0 is a platform in which content and applications are consistently modified by all web users in a participatory and collaborative way, rather than being only created and published by individuals [31]. This platform augments the experience of the users, who then take over the role of creators and seek interactivity and proactive virtual communities on the web [35].

The rapid increase of social media started a whole new era for businesses and brands, which push them to seek new, interactive ways of reaching and engaging their customers [36]. In 2012, Internet users spent more time on social media than any other category of web sites [37]; this trend gave researchers a reason to believe that the use of social media affects consumer desire, purchase decisions and word of mouth, thus changing the environment of marketing communication in the last few decades [38]. Moreover, this phenomenon has expanded marketing channels, reaching more than two-thirds of all Internet users and thus providing incomparable opportunities for brand and reputation building [39].

More than two-thirds of online users worldwide visit and engage with social networks and blogs [40]. Xiang and Gretzel [30] point out that social media has become enormously influential, to the extent that its application to the music festivals market cannot be ignored by marketers. In music festivals, the success may be dependent on the marketing of entertainment [41]. Through social media, it is faster and easier to gain unmediated customer insights [30]. Thanks to smartphones, people have a more comprehensive access to information, especially through online social network platforms such as Facebook, Twitter, YouTube and Instagram. Thus, it has become more convenient to advertise online to attract visitors on a larger scale

Online social networks enable users to connect, search and share content and spread information. A great number of websites embed links to social networks pages for professional use, as in the case of LinkedIn, Facebook and MySpace, or to sharing platforms like Flickr and YouTube, to display content [40]. Social networks, with simple technologies and practical settings of privacy control, provide a streamlined experience to an increasing number of users and a significant tool to marketers [42]. The author has selected the major 
categories of social media channels, which are YouTube (video), Facebook, Instagram and Twitter (microblogging) for this research study.

Video content is gaining popularity among web users in their daily lives. Web users are allowed to create and distribute their own content to audiences and the web has been turned into a major channel for multimedia delivery [35]. According to Safko [43] (p. 449), "Facebook provides a platform for users to quickly connect with friends, family, co-workers and acquaintances in various network groups". Due to its popularity, Facebook is used to as a tool to promote a new product and service and also deliver word of mouth through social network [43].

Twitter is a microblogging service where users can write and post about any topic, follow other users and be followed back [44]. Once they become a follower on Twitter, a user receives all the messages (commonly known as tweets) from the user followed. There are three common ways of responding to a tweet: "RT" which stands for retweet and allows to share and comment a tweet; ' @' followed by the user identifier, to address a post to someone; '\#' followed by a word, is the so-called "hashtag" [44] (p. 591) and will show the public post within a group of tweets containing the same hashtag.

\subsection{Consumer Behavior and Motivations}

\subsubsection{Consumer Behavior Theories}

Engel et al. [45] established a model of consumer decision making, which is also known as Engel-Kollat-Blackwell (EKB) model. It explains decision process of consumers and how choices are made when consumers choose among a list of alternatives available [46]. However, environmental factors may be additional variables which influence the formation of consumer decisions [46]. The Engel-Kollat-Blackwell (EKB) model presents five core stages of the decision-making process: problem recognition; information search; evaluation of alternatives; purchase decision; and post-purchase behavior [45] (Figure 1).

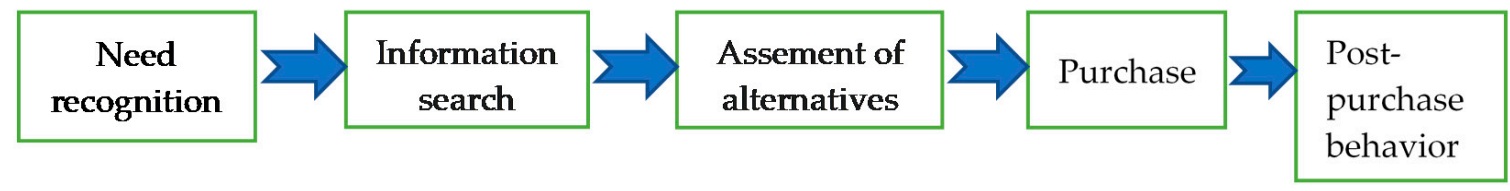

Figure 1. Stages of online purchase decision-making process. Source: Adapted from Osei and Albenyin [46].

\subsubsection{Motivational Theories "Push and Pull"}

The push and pull framework was extensively used to measure and investigate motivations for event attendance [22]. A tourism experience can play an important part in meeting a person's psychological needs [47]. Push and pull factors were categorized forces in motivation and, as Snepenger et al. [48] pointed out, people travel because they are "pushed from internal imbalances and the need to seek an optimal level of arousal, as well as pulled by the offerings of a specific destination". Within the individual, the psychological forces that conceptualize the push factors act as an impetus for travel [22], including necessities such as rest, escape and leisure. These push factors as well as the demand-side approach provides some insight into the decision-making process of tourists and also tie in with Maslow's [49] hierarchy of need theory and Plog's [50] psychographic theory.

On the other hand, pull factors are commonly seen from a supply-side dimension [47] and are the external forces that arise by participating in a certain activity, the encouragement of visiting a specific place, or the production of destination [2]. Other resources include recreational activities, special events or festivals, cultural resources and other entertainment opportunities [47]. Push factors go ahead of pull factors in the process of decision making in tourism. This means that a person first feels the internal demand for travel and only then ruminates what places to go, with the support of pull factors. However, Yoon and Uysal [51] argue that push factors are provoked, reacted and reinforced by pull factors. Enjoying the artists' performance being the motivation is popular for local repeaters, local 
families and the young party set [52]. It is common that artists' performance is important in music festivals. Understanding visitors' motivation for attending a music festival is crucial; the line-up of artists is important, and visitors intend to buy more tickets if any artists are famous or the festival includes one of their favorite artists.

\subsection{Research Design and Approach}

A positivist approach was adopted to collect data for this research. The reason behind this is found in Remenyi et al. [53], as they claim positivism applies to those situations where "working with an observable social reality" is preferred and where only phenomena that can be observed will lead to the collection of reasonable data. A positivist approach allows to collect data that would facilitate the estimation of quantitative statistics and allow hypotheses to be tested [54]. For this research, in terms of collecting the data, it is understood that the value of statistics contributes the most and has the most significant role in analyzing the data.

It is common to find the results of "research" all around and difficult to avoid the term "research" [54]. Research is defined as "something that people undertake in order to find out things in a systematic way, thereby increasing their knowledge [54] (p. 5). In this definition, "systematic way" and "to find out things" are the key terms, as "systematic" provides research based on logical relationships, not just a belief [55]. Numerous academics perceive a problem with a gap between basic, fundamental or pure reach and applied research [54]. There are many existing studies about "event marketing" and "social media advertising"; however, there are limited marketing or advertising studies focused on "music festival" industries.

\section{Hypotheses}

Based on the previous discussions, the authors focused on the use of social media as means to advertise music festivals, to investigate the degree of persuasion level for social media users' decision making to purchase the music festival tickets. Thus, the following hypotheses are proposed:

Hypothesis 1. Within the focused element (such as festival atmosphere dominant content) music festival advertising in social media persuade consumers to purchase music festival tickets.

H1: Music festival advertising with a focused element in social media content can persuade consumers to purchase music festival tickets.

H0: Music festival advertising with a focused element in social media content cannot persuade consumers to purchase music festival tickets.

Hypothesis 2. Consumers follow or like a certain music festival page or channel on social media and there are more possibilities of being persuaded to purchase the ticket.

H1: There are relationships between following or liking a certain music festival page and being persuaded to purchase the ticket.

H0: There are no relationships between following or liking a certain music festival page and being persuaded to purchase the ticket.

\section{Hypothesis 3.}

H1: Social media advertising is influential to persuade festival goers to purchase the ticket.

H0: Social media advertising is not influential to persuade festival goers to purchase the ticket. 


\section{Methods}

\subsection{Research Strategy}

A quantitative research method was chosen as the methodology for this research. A quantitative method is particularly applicable for the purposes of this research, where the numeric statistics of the impact of social media advertising on music festival are presented (where the connection between several different variables had to be established through interpretation). A self-administered offline questionnaire was applied as the research instrument and it was delivered by hand to the respondents. Saunders et al. [54] state that questionnaire is highly popular as it allows "the collection of a large among of data from a sizeable population in a highly economical way". Moreover, survey strategy is comparatively simple to understand and explain, and it allows to collect quantitative data using descriptive and inferential statistics which "suggest possible reasons for particular relationships between variables and to produce models of these relationships" [54] (p. 144).

This offline questionnaire was built and composed of 14 questions, including only close-ended questions. The main type of question includes multiple choices and a Likert scale. Close-ended questions can be used for specific information or to confirm a fact or opinion [54]. The multiple choices are focused on general perception and experience on music festival advertising on social media. The Likert scale is used to investigate respondents persuasive feeling towards music festival advertising on social media. In terms of the layout of questionnaire, is it designed with respondents' demographic information, general perception of music festival advertising on social media, and the degree of persuasion by social media advertising.

\subsection{Data Collection}

This research aims to investigate the degree of persuasion by social media advertising of a music festival and there is no limitation of specific groups of participants. Therefore, a method of random sampling was applied to this research, which provides an estimated value of the population characters and a measure of the reliability of the estimates made [56]. Before the main survey, a pilot study was conducted by the authors of the current study and two research assistants to ensure there is no ambiguity, confusion or uncertainty in the questionnaire. It was carried out from July to September 2018 with 26 people who were associates of the researchers of the current study in different demographic backgrounds in London, United Kingdom. After modifying the uncertain and confusing expressions in the questionnaire based on the findings of the pilot study, the main questionnaires were composed, distributed and collected from December 2018 to February 2019 using the snowballing sample method. For the sake of objectivity, the participants were approached and chosen using random selection of basic demographic figures such as gender, age groups and nationalities.

In order to help in answering research questions, a set of method and analysis tools were used to find information. In this study, numerical data are in the main analysis. To analyze the collected quantified data, the statistical software SPSS is used to investigate different frequencies of variables and the relationships between different variables. SPSS is a common software tool to analyze quantitative data. The majority of the questions were analyzed by frequencies analysis. Descriptive analysis was used to investigate Likert scale questions and other demographic information. To identify relationship between variables, Cross Tabulation analysis was applied. Cross Tabulation analysis was selected specifically to analyze the possibilities of persuasion with a mix of two different conditions applied.

\section{Results}

\subsection{Demographic Profile of Respondents}

In total, there were 125 respondents that participated in this offline survey; 68 were males (54.4\%) and 57 were females (45.6\%). Age groups were classified from "under 18 years" up to "over 55 years". The age group of "18-24 years old" resulted the largest portion $(52.0 \%)$. The majority of respondents have participated music festival " $0-2$ times" 
(71.2\%) and a few have participated " $3-5$ times" (23.2\%) in the past five to seven years. "Social media" (46\%) was the most efficient way for respondents to hear the music festival by using frequency analysis. Referring to the social media channel where most music festival advertisements are found, 42\% respondents insisted the choice of "Facebook", and other results include "Instagram" (32\%) and "YouTube" (7\%). There are 77.62\% respondents that watch music festival advertising if these pop up on their social media. Moreover, generally, there are $37.6 \%$ respondents claiming that "Artists Line-up" information mostly attracts in the social media advertisement, others being 28\% "Festival Atmosphere" and 16\% "Artist Line-up pictures". "Video advertising" (57.6\%) was found as the most appealing advertising format of respondents by using frequency analysis. The following most appealing advertising format of social media is "Image advertising" (28.0\%).

\subsection{Perception towards Music Festival Advertising on Social Media}

The general perception towards music festival advertising on social media has been tested. Firstly, for the perception of "music festival advertising on social media is easy to notice", 55.2\% of respondents chose "Agree" and 32\% of respondents "Strongly agree". Only $4.8 \%$ of respondents selected "Disagree". The highest responses for "music festival on social media are trust worthy" resulted in "Neutral" with $43.2 \%$ and following highest as "Agree" with $38.4 \%$. A percentage of 56.8\% of respondents "Agree" that the advertising is "engaging and entertaining" while less than 10\% "Disagree" or "Strongly disagree".

Furthermore, $16.41 \%$ of respondents answered "Strongly agree" to the perception of "enjoy receiving promotional information" while $41.6 \%$ of them selected "Agree". Respondents who claimed they would look for social media advertisement if they decide to go to music festival were $27.2 \%$ of "Strongly agree" and $44 \%$ of "Agree", respectively. A total of $44.8 \%$ of the respondents agreed and $17.6 \%$ of the respondents strongly agreed (not including the percentage of "Neutral") to the perception of "I think social media advertisements encourage me to look into music festival details. Only $9.6 \%$ of the respondents disagreed and $1.6 \%$ strongly disagreed.

It is recognized that the general perceptions of respondents toward music festival advertising on social media are positive. The sum of "Strongly agree" and "Agree" percentage is more likely higher than either the percentage of "Neutral" or the sum of "Strongly disagree" and "Disagree" in all six statements above. Therefore, it can be seen that music festival advertising on social media is easy to notice, trustworthy and engaging and entertaining. Moreoever, it can be seen that respondents positively perceived engaging as to "enjoy receiving promotional information", "look for social media advertisement if decide to go so music festival" and "social media advertisements encourage to look into festival details" to social media advertisement.

\subsection{Persuasion}

According to the survey data of persuasion by music festival advertising on social media, those who answered "Agree" to the statement of "I may be persuaded to purchase the music festival ticket if the ad is with high quality" total $55.2 \%$ compared to the $4.8 \%$ who answered "Disagree". There are 53.6\% respondents who agreed that they may be persuaded to purchase the music festival ticket if the ad is "engaging and entertaining", while $4.8 \%$ of respondents disagreed. Among the respondents, 52.8\% of them agreed and $21.6 \%$ strongly agreed that they may be persuaded to purchase the music festival ticket if the advertisement is focused on "Artist Line-up". On the other hand, 5.6\% of the respondents disagreed to the above statement. Furthermore, 39.2\% of the respondents agreed and $22.4 \%$ of the respondents strongly agreed that they may be persuaded to purchase the ticket if the ad is focused on "festival atmosphere", while $7.2 \%$ of the respondents disagreed.

Noticeably, the percentage of "Agree" options of each statement was higher that "Neutral" and "Disagree" options. Therefore, it can be seen that more respondents may be persuaded to purchase the music festival ticket if the music festival ads on social media are "with high quality", "engaging and entertaining", "focused on artist line-up" or "focused 
on music festival atmosphere". Within the sum of the percentage of "Agree" and "Strongly agree" from each statement, the respondents are more likely to be persuaded if the ad is when the ad is focused on "Artist Line-up" (74.4\%). Males and females have different results for the most influential element to buy a music festival ticket. Males consider "Friend or Family" as the most influential (40\%), whilst female answered, "Artist Line-up" (35\%). The second highest for males was the "Artist Line-up" with 37\%, and for females was "Friends or Family" with 25\%. "Festival atmosphere" is the third highest for both males and females with $13 \%$ and $21 \%$, respectively. Males and females both consider "Festival Advertisement" and "Reputation of Festival" to be less significant than the other three aspects.

\subsection{Importance of Artists Line-Up}

Eighty-three respondents answered that they found music festival advertising on social media. Among them, 72\% of the respondents always check festival artists line-up and $28 \%$ of them do not. Moreover, "Artist Line-up" (31.37\%) was identified as the most influential element that would potentially make them to purchase the ticket among users of social media. "Friends or Family $(25.30 \%)$ " resulted as the second most effective element. Therefore, based on the cross-tabulation analysis with "social media", respondents tend to consider "Artist Line-up" as the most influential element or content for music festival advertising.

The largest age group of the respondents is the "18-24 years old" bracket (52\%) and regarding the most influential element to potentially make them buy the music festival ticket, 34\% of the respondents selected "Artist Line-up", followed by 29\% with "Friends and Family". The second largest age group is "25-34 years old" (32\%) and "Friends or Family" (43\%) resulted as the most influential element and "Artist Line-up" (38\%) as second. Overall, based on the cross-tabulation analysis, more than two-thirds of the respondents always check the artist line-up for music festival. Moreover, it can be considered that artist line-up seems to be the most influential element of the music festival advertising to respondents who often find the ad on social media and age group between 18 and 24 years old.

"Facebook" resulted as the social media channel where most respondents see music festival advertisement, and it was identified that $30.58 \%$ of the respondents generally watch the ad if it pops up on Facebook. Regarding "Instagram" as the platform with the second most seen music festival advertisements, it resulted that $27.67 \%$ of the respondents generally watch the ad if it pops up on Instagram. As for the cross tabulation between social media channel and ad formats, "Facebook" with "Video advertising" (38.73\%) notes the most appealing format on social media. Additionally, "Image advertising" (10.19\%) was the next appealing. With "Instagram", "Video advertising" (19.47\%) was also regarded as the most appealing format, followed by "Image advertising" (13.33\%).

\subsection{Music Festival Advertisement as "Engaging and Entertaining"}

The respondents who agreed (28.74\%) and strongly agreed (10.26\%) that music festival advertising on social media is trustworthy have purchased music festival tickets "1-3 times" after seeing the social media advertisements. Meanwhile, the respondents who purchased music festival tickets "4-6 times" after seeing the social media advertisements agreed $(7.70 \%)$ and strongly agreed (3.30\%) that the advertising is trustworthy (Table 1$)$.

The respondents who believe music festival advertising on social media is "engaging and entertaining" agreed (44.66\%) and strongly agreed $(12.18 \%)$ that they may be persuaded to purchase the festival ticket if the ad is "engaging and entertaining" (Table 2).

Moreover, the respondents who agreed (45.68\%) and strongly agreed $(14.21 \%)$ that music festival advertising on social media is "engaging and entertaining" have purchased music festival tickets "1-3 times". The respondents agreed (41.60\%) and strongly agreed $(16.23 \%)$ that they would purchase the festival ticket if the ad is high quality. The respondents agreed (35.53\%) and strongly agreed (13.20\%) that they would purchase the festival 
ticket if the ad is focused on "Artist Line-up" and agreed (32.65\%) and strongly agreed $(11.23 \%)$ to purchase a ticket if the ad is focused on "festival atmosphere".

According to the data analyzed above, respondents who think the music festival advertising on social media is "engaging and entertaining" have experienced purchasing a music festival ticket "1-3 times". Among the focuses of the advertisements, for the respondents who answered music festival advertising on social media is engaging and entertaining, there are more possibilities to be persuaded to purchase the ticket if the ad is focused "Artist Line-up" (Table 3).

Table 1. Credibility of social media and purchasing ticket.

\begin{tabular}{|c|c|c|c|c|c|c|c|}
\hline \multicolumn{8}{|c|}{ Have You Ever Purchased Music Festival Ticket after Seeing the Social Media Advertisements? } \\
\hline & & 10 Times+ & 7-9 Times & 4-6 Times & 1-3 Times & Never & Total \\
\hline \multirow{5}{*}{$\begin{array}{l}\text { I think } \\
\text { music festival } \\
\text { advertising on social } \\
\text { media is trustworthy }\end{array}$} & Strongly agree & 0 & 0 & 3 & 10 & 0 & 13 \\
\hline & Agree & 1 & 1 & 7 & 28 & 11 & 48 \\
\hline & Neutral & 1 & 1 & 3 & 27 & 22 & 54 \\
\hline & Disagree & 0 & 0 & 2 & 1 & 5 & 8 \\
\hline & Strongly disagree & 0 & 0 & 0 & 0 & 2 & 2 \\
\hline Total & & 2 & 2 & 15 & 66 & 40 & 125 \\
\hline
\end{tabular}

Table 2. Engaging and entertaining advertisement and decision making.

I may be Persuaded to Purchase the Music Festival Ticket If the Ad Is Engaging and Entertaining

\begin{tabular}{cccccccc}
\hline & & Strongly Agree & Agree & Neutral & Disagree & Total \\
\hline \multirow{3}{*}{$\begin{array}{c}\text { I think overall, music festival } \\
\text { advertising on social media is } \\
\text { engaging and entertaining }\end{array}$} & Strongly agree & 11 & 12 & 2 & 0 & 25 \\
\cline { 2 - 7 } & Agree & 6 & 44 & 19 & 2 & 71 \\
\cline { 2 - 7 } & Neutral & 0 & 9 & 8 & 3 & 20 \\
\hline Total & Disagree & 0 & 67 & 35 & 6 & 125 \\
\hline
\end{tabular}

Table 3. "Engaging and entertaining" advertisement and purchase of ticket.

\begin{tabular}{|c|c|c|c|c|c|c|c|}
\hline \multicolumn{8}{|c|}{ Have You Ever Purchased Music Festival Ticket after Seeing the Social Media Advertisements? } \\
\hline & & 10 Times+ & 7-9 Times & 4-6 Times & 1-3 Times & Never & Total \\
\hline \multirow{4}{*}{$\begin{array}{l}\text { I think overall, } \\
\text { music festival advertising } \\
\text { on social media is engaging } \\
\text { and entertaining }\end{array}$} & Strongly agree & 0 & 2 & 5 & 14 & 4 & 25 \\
\hline & Agree & 2 & 0 & 9 & 45 & 15 & 71 \\
\hline & Neutral & 0 & 0 & 1 & 7 & 12 & 20 \\
\hline & Disagree & 0 & 0 & 0 & 0 & 9 & 9 \\
\hline Total & & 2 & 2 & 15 & 66 & 40 & 125 \\
\hline
\end{tabular}

\subsection{Music Festival Promotional Information}

It is also noticeable that among those respondents who agreed that they enjoy receiving music festival promotional information from social media, $26.43 \%$ of the respondents have followed or liked "1-3 times" the music festival social media page or channel because they learned about it through social media. A total of $15.62 \%$ of the respondents have followed or liked "4-6 times" (see Table 4). In terms of the experience of purchasing music festival tickets after seeing the social media advertisements, $32.48 \%$ of respondents have purchased "1-3 times" and 9.60\% of the respondents have bought " $4-6$ times" (see Table 5). 
Table 4. Receiving promotional information and following social media channel.

\begin{tabular}{cccccccc}
\hline Have You Ever Followed or Liked Music Festival Social Media Page or Channel because You Learned about It through \\
Social Media?
\end{tabular}

Table 5. Receiving promotional information and purchasing the ticket.

\begin{tabular}{|c|c|c|c|c|c|c|c|}
\hline \multicolumn{8}{|c|}{ Have You Ever Purchased Music Festival Ticket after Seeing the Social Media Advertisements? } \\
\hline & & 10 Times+ & 7-9 Times & 4-6 Times & 1-3 Times & Never & Total \\
\hline \multirow{5}{*}{$\begin{array}{l}\text { I think I enjoy } \\
\text { receiving music festival } \\
\text { promotional information } \\
\text { from social media }\end{array}$} & Strongly agree & 0 & 1 & 4 & 13 & 2 & 20 \\
\hline & Agree & 1 & 1 & 9 & 32 & 9 & 52 \\
\hline & Neutral & 1 & 0 & 2 & 17 & 11 & 31 \\
\hline & Disagree & 0 & 0 & 0 & 4 & 15 & 19 \\
\hline & Strongly disagree & 0 & 0 & 0 & 0 & 3 & 3 \\
\hline Total & & 2 & 2 & 15 & 66 & 40 & 125 \\
\hline
\end{tabular}

Furthermore, the respondents claimed that they may be persuaded to purchase the music festival ticket if the ad is focused on: the "Festival atmosphere" (22.45\%), "Artist lineup" (19.29\%), being "Engaging and entertaining" (31.46\%) and "High quality" (38.55\%). It is distinguished that there are higher numbers of respondents who selected "Agree" with all four options than "Disagree".

Overall, based on the cross-tabulation analysis, it is interesting to find that the percentage of "Agree" was the highest among the scales for the following statements: "Have you ever followed or liked music festival social media page or channel because you learned about it through social media?" and "Have you ever purchased music festival ticket after seeing the social media advertisements?" Thus, it can be said that respondents who agreed to receive promotional information are more likely to follow and like the music festival social media page or channel compared to the respondents who disagreed. Furthermore, as mentioned above that there were more respondents who agreed than disagreed to all the statement of being persuaded to purchase the ticket if the ad is focused on four elements, "High quality" was the element that gained the highest response. Based on this data, it can be considered that respondents who follow or like the music festival page on social media channel are more likely to purchase the ticket if the advertisement is created with high quality.

\subsection{Social Media Advertising}

As Table 6 indicates, it is proven that the respondents who agree or strongly agree that they will look for social media advertisement if they decide to go to music festival, have followed or liked the music festival social media page or channel. It was identified that $27.45 \%$ of respondent have followed or liked "1-3 times" while $14.58 \%$ of the respondents did so "4-6 times". In addition, $34.65 \%$ of the respondents have purchased the ticket "1-3 times" and 7.47\% have purchased "4-6 times" (see Tables 6 and 7). 
Table 6. Cross tabulation of social media advertising with following social media page.

\begin{tabular}{cccccccc}
\hline Have You Ever Followed or Liked Music Festival Social Media Page or Channel because You Learned about It through \\
Social Media?
\end{tabular}

Table 7. Cross tabulation of social media advertising and purchasing ticket.

\begin{tabular}{|c|c|c|c|c|c|c|c|}
\hline \multicolumn{8}{|c|}{ Have You Ever Purchased Music Festival Ticket after Seeing the Social Media Advertisements? } \\
\hline & & 10 Times+ & 7-9 Times & 4-6 Times & 1-3 Times & Never & Total \\
\hline \multirow{5}{*}{$\begin{array}{l}\text { I think I will look for } \\
\text { social media advertisement } \\
\text { if I decide to go to } \\
\text { music festival }\end{array}$} & Strongly agree & 1 & 0 & 7 & 21 & 5 & 34 \\
\hline & Agree & 1 & 1 & 5 & 34 & 14 & 55 \\
\hline & Neutral & 0 & 1 & 3 & 6 & 10 & 20 \\
\hline & Disagree & 0 & 0 & 0 & 5 & 7 & 12 \\
\hline & Strongly disagree & 0 & 0 & 0 & 0 & 4 & 4 \\
\hline \multicolumn{2}{|l|}{ Total } & 2 & 2 & 15 & 66 & 40 & 125 \\
\hline
\end{tabular}

Respondents who agree that they think social media advertisements encourage them to look into music festival details have followed or liked the social media page or channel. A total of $29.48 \%$ of the respondents have followed or liked "1-3 times" and $16.67 \%$ of the respondents have followed or liked "4-6 times" (see Table 8). It can be viewed that those respondents who agreed that they would look for social media advertisement if they decide to go to music festival are more likely to follow or like social media channel or page and purchase music festival ticket.

Table 8. Cross tabulation of social media encouragement and purchasing ticket.

\begin{tabular}{cccccccc}
\hline Have You Ever Followed or Liked Music Festival Social Media Page or Channel because You Learned about It through \\
Social Media?
\end{tabular}

\subsection{Purchasing Music Festival Ticket}

The response "1-3 times" (66.53\%) is the highest frequency that respondents have purchased a music festival ticket. Among these specific respondents, there are $27.73 \%$ of them who agreed that they are easily persuaded by social media advertisement in general and $25.67 \%$ of them are "Neutral" to the statement (see Table 9). This result can be seen as respondents who are easily persuaded by social media advertisement in general have higher possibilities of purchasing music festival ticket. 
Table 9. Purchase ticket persuasion by social media advertisement.

\begin{tabular}{|c|c|c|c|c|c|c|c|}
\hline \multicolumn{8}{|c|}{ I Am Easily Persuaded by Social Media Advertisement in General } \\
\hline & & Strongly Agree & Agree & Neutral & Disagree & Strongly Disagree & Total \\
\hline \multirow{5}{*}{$\begin{array}{c}\text { Have you ever } \\
\text { purchased music } \\
\text { festival ticket after } \\
\text { seeing the social } \\
\text { media advertisements? }\end{array}$} & 10 times+ & 0 & 1 & 1 & 0 & 0 & 2 \\
\hline & $7-9$ times & 2 & 0 & 0 & 0 & 0 & 2 \\
\hline & $4-6$ times & 2 & 2 & 8 & 2 & 1 & 15 \\
\hline & $1-3$ times & 4 & 27 & 25 & 10 & 0 & 66 \\
\hline & Never & 3 & 7 & 11 & 6 & 13 & 40 \\
\hline Total & & 11 & 37 & 45 & 18 & 14 & 125 \\
\hline
\end{tabular}

Furthermore, respondents who have purchased " $1-3$ times" claimed that they may be persuaded to purchase the music festival ticket if the ad is focused on "Festival atmosphere" (30.61\%), "Artist line-up" (35.53\%), being "Engaging and entertaining" (39.58\%) and "High quality" (40.58\%). It is identified that there are many respondents who may be persuaded to purchase the ticket if the ad is engaging and entertaining.

\section{Discussion and Conclusions}

\subsection{Discussion}

Social media not only keeps gaining popularity in the event industry marketing and operation, but also it is a strategic and valuable tool to promote a festival event in a more sustainable way. The purpose of this study is to examine how social media advertising can persuade customers to buy music festival tickets. The objectives included to investigate the relationship between the use of social media advertising and the purchase of music festival tickets; to examine the impact of social media advertising contents to persuade customers to purchase music festival tickets; and to draw conclusions on how significantly social media advertisements persuade customers to purchase music festival tickets. Most of the existing literature regarding social media marketing on events and festivals is on advertising, consumer behavior, reputation enhancing and cost saving on marketing activities. The current study adds value by filling the gap in discussing the types of the music festival marketing currently investigated, social media marketing platforms, consumer behaviors, motivation with push-pull theories that aim to give insights into consumer behavior and their motivations especially in terms of decision making on festival attendance.

\subsection{Theoretical Contribution}

The current study presents an innovative theoretical contribution investigating the main theories in the marketing field, and specifically the contemporary festival marketing field associated with social media, which has been rapidly growing in recent years worldwide. The study proposed hypotheses to measure the degree of persuasion by music festival advertising on social media as a case in the United Kingdom. From examination of the rigorous theoretical discussion and measuring hypotheses, the following key findings were identified: (a) Music festival advertising with a focused element on social media content can persuade consumers to purchase music festival ticket; (b) There are relationships between following or liking a certain music festival page and being persuaded to purchase the ticket; and (c) Social media is influential to persuade festival goers to purchase the ticket.

Through the current study, the perception of music festival advertising on social media and the content of social media advertising were analyzed to find the degree of persuasion by social media advertising at different assumptions examined in this study towards music festival advertising on social media. As a result, general perception concluded with mostly positive views toward music festival advertising on social media. According to the findings, artist line-up was considered to be the most appealing source for the social media advertising. Facebook was perceived as the platform with the most music 
festival advertisement seen, and video advertising was considered the most appealing and attractive ad format on social media. The persuasion by music festival advertising on social media has resulted in mostly positive attitudes, whereas most of the respondents agreed to be persuaded to purchase the festival ticket at different conditions. The study deepened our intuitive understanding of the role of social media on its impact to the actual decision-making activities of festival attendees by measuring a series of hypotheses.

\subsection{Managerial Implications}

In the current study which investigated persuasion with specific assumptions applied, a set of two different variables were investigated using a cross-tabulation tool. It was found that, regarding the element of advertisement in social media content, perceptions toward the social media advertising, the condition of advertising and the element focused on social media content have impacts on persuasion of purchasing the festival ticket. The global festival industry needs to maximize the benefits and advantages of social media marketing tools in developing and advertising festivals more in a long-term, sustainable way. This can be done not only by private entrepreneurs but also by public government agencies, quasi-government associations and voluntary local community residents.

It is evident that social media has an influence on festival attendees' motivation to attend festivals. Based on the results of the current study, several recommendations are suggested as follows. The social media should be trustworthy, objective, entertaining, and informative in detail to successfully lead to ticket purchase. Social media can also play a critical role in maintaining the relationship between the festival organizers and attendees not only during the festival period but also before and after the festival by continuous communications that link the two parties. Furthermore, the main stakeholders in the festival industry should share common interests and resources for sustainable collaboration to gain mutual benefits by maximizing the efficient function of social media.

\subsection{Limitations and Further Research}

There were a few limitations to this study, and these are within the data collection. Although this survey was distributed randomly, most of the respondents are crowded in the younger groups. This may affect the validity of data and relevant findings. It could be better to have both online and offline surveys to have more variety in respondents' demographics. Regarding the sample size, due to the limitation of accessing respondents in the specific type of festival to collect data, the number of respondents can be increased to increase the reliability of the questionnaire survey.

Moreover, it can be suggested that the continuation of research in the specific event area can lead to the development of social media advertising. Research topics with specific events had limited existing literature to support the idea. More specific event areas are to be identified and investigated such as persuasion by themed event, music festival advertising effect, influential advertising strategies for music festivals, and more investigation on the global music festival market. Further research questions can be approached, such as why music festival advertising on a particular social media channel is more efficient than others, what are the efficient advertising strategies if people are not interested in artist line-up, and what is the relationship between music festival advertising and different consumer behavior. Finally, the statistical techniques could also go further, namely, through a correlation analysis of the variables, statistical inference and even the use of multiple linear regressions for a more robust validation of the defined research hypotheses.

Author Contributions: Conceptualization, L.Q. and A.I.; methodology, A.I.; formal analysis, T.J.L. and L.Q.; resources, A.I.; data curation, J.S.K.; writing-original draft preparation, L.Q. and A.I.; writing-review and editing, T.J.L. supervision, T.J.L.; funding acquisition, L.Q. All authors have read and agreed to the published version of the manuscript. 
Funding: This paper was supported by Zhejiang Province Education Science Planning Key Projects Fund (Grant number: 2021SB059) in China. This paper was supported by the Sehan University Research Fund in 2021 (Grant number: sh2096) in Korea.

Institutional Review Board Statement: The study was conducted according to the guidelines of the Declaration of Helsinki and approved by the Institutional Review Board of the Ningbo Polytechnic in China (11 May 2021).

Informed Consent Statement: Informed consent was obtained from all subjects involved in the study.

Data Availability Statement: Data sharing not applicable.

Conflicts of Interest: The authors declare no conflict of interest. The funders had no role in the design of the study; in the collection, analyses, or interpretation of data; in the writing of the manuscript, or in the decision to publish the results.

\section{References}

1. Arasli, H.; Abdullahi, M.; Gunay, T. Social Media as a Destination Marketing Tool for a Sustainable Heritage Festival in Nigeria: A Moderated Mediation Study. Sustainability 2021, 13, 6191. [CrossRef]

2. Yolal, M.; Çetinel, F.; Uysal, M. An Examination of Festival Motivation and Perceived Benefits Relationship: Eskişehir International Festival. J. Conv. Event Tour. 2009, 10, 276-291. [CrossRef]

3. Kitagawa, T. The Experience of Place in the Annual Festival Held in an Amazigh Village in Southern Tunisia. Sustainability 2021, 13, 5479. [CrossRef]

4. Sheth, J.; Uslay, C. Implications of the Revised Definition of Marketing: From Exchange to Value Creation. J. Public Policy Mark. 2007, 26, 302-307. [CrossRef]

5. Chaffey, D.; Ellis-Chadwick, F. Digital Marketing; Pearson: London, UK, 2019.

6. Saravanakumar, M.; SuganthaLakshmi, T. Social Media Marketing. Life Sci. J. 2012, 9, 4444-4451.

7. Zhang, Y.; Park, K.-S.; Song, H. Tourists' Motivation, Place Attachment, Satisfaction and Support Behavior for Festivals in the Migrant Region of China. Sustainability 2021, 13, 5210. [CrossRef]

8. Duffett, R. Facebook Advertising's Influence on Intention-to-Purchase and Purchase amongst Millennials. Internet Res. 2015, 25, 498-526. [CrossRef]

9. Kumar, A.; Bezawada, R.; Rishika, R.; Janakiraman, R.; Kannan, P. From Social to Sale: The Effects of Firm-Generated Content in Social Media on Customer Behavior. J. Mark. 2016, 80, 7-25. [CrossRef]

10. Schultz, D.; Peltier, J. Social Media's Slippery Slope: Challenges, Opportunities and Future Research Directions. J. Res. Interact. Mark. 2013, 7, 86-99. [CrossRef]

11. Bowdin, G.; Allen, J.; Harris, R.; McDonnell, I.; O'Toole, W. Events Management; Routledge: England, UK, 2012.

12. Lee, I.S.; Lee, T.J.; Arcodia, C. The Effect of Community Attachment on Cultural Festival Visitors' Satisfaction and Future Intentions. Curr. Issues Tour. 2014, 17, 800-812. [CrossRef]

13. Duarte, P.; Folgado-Fernández, J.A.; Hernández-Mogollón, J.M. Measurement of the Impact of Music Festivals on Destination Image: The Case of a Womad Festival. Event Manag. 2018, 22, 517-526. [CrossRef]

14. Hudson, S.; Thal, K. The Impact of Social Media on the Consumer Decision Process: Implications for Tourism Marketing. J. Travel Tour. Mark. 2013, 30, 156-160. [CrossRef]

15. Martín, J.C.; Pagliara, F.; Román, C. The Research Topics on E-Grocery: Trends and Existing Gaps. Sustainability 2019, $11,321$. [CrossRef]

16. Zeng, F.; Huang, L.; Dou, W. Social Factors in User Perceptions and Responses to Advertising in Online Social Networking Communities. J. Interact. Advert. 2009, 10,1-13. [CrossRef]

17. Shaw, A. Council Post: What Marketers Can Learn from The Fyre Festival's Influencer Marketing Fiasco 2019. Available online: https:/ / www.forbes.com/sites/forbescommunicationscouncil/2019/04/16/what-marketers-can-learn-from-the-fyrefestivals-influencer-marketing-fiasco/\#1c509cff1308 (accessed on 16 April 2021).

18. Pereira, L.; Jerónimo, C.; Sempiterno, M.; da Costa, R.L.; Dias, Á.; António, N. Events and Festivals Contribution for Local Sustainability. Sustainability 2021, 13, 1520. [CrossRef]

19. Manthiou, A.; Lee, S.; Tang, L.; Chiang, L. The Experience Economy Approach to Festival Marketing: Vivid Memory and Attendee Loyalty. J. Serv. Mark. 2014, 28, 22-35. [CrossRef]

20. Prentice, R.; Andersen, V. Festival as Creative Destination. Ann. Tour. Res. 2003, 30, 7-30. [CrossRef]

21. Lopera-Mármol, M.; Jiménez-Morales, M. Green Shooting: Media Sustainability, A New Trend. Sustainability 2021, $13,3001$. [CrossRef]

22. Yoo, I.Y.; Lee, T.J.; Lee, C.K. Effect of Health and Wellness Values on Festival Visit Motivation. Asia Pac. J. Tour. Res. 2015, 20, 152-170. [CrossRef]

23. Leenders, M. The Relative Importance of the Brand of Music Festivals: A Customer Equity Perspective. J. Strateg. Mark. 2010, 18, 291-301. [CrossRef]

24. Getz, D. Festivals, Special Events and Tourism; Van Nostrand: New York, NY, USA, 1991. 
25. Conway, T.; Whitelock, J. Relationship marketing in the subsidised arts: The key to a strategic marketing focus? Eur. J. Mark. 2007, 41, 199-222. [CrossRef]

26. Anderton, C. Music Festival Sponsorship: Between Commerce and Carnival. Arts Mark. Int. J. 2011, 1, 145-158. [CrossRef]

27. Lanier, C.D., Jr.; Hampton, R.D. Experiential Marketing: Understanding the Logic of Memorable Customer Experiences. In Memorable Customer Experiences; Lindgreen, A., Vanhamme, J., Beverland, M., Eds.; Gower: Surrey, UK, 2009; pp. 9-23.

28. Brown, J.; Broderick, A.; Lee, N. Word of Mouth Communication within Online Communities: Conceptualizing the Online Social Network. J. Interact. Mark. 2007, 21, 2-20. [CrossRef]

29. Keller, K. Building Strong Brands in A Modern Marketing Communications Environment. J. Mark. Commun. 2009, 15, 139-155. [CrossRef]

30. Xiang, Z.; Gretzel, U. Role of Social Media in Online Travel Information Search. Tour. Manag. 2010, 31, 179-188. [CrossRef]

31. Kaplan, A.; Haenlein, M. Users of the World, Unite! The Challenges and Opportunities of Social Media. Bus. Horiz. 2010, 53, 59-68. [CrossRef]

32. Guesalaga, R. The Use of Social Media in Sales: Individual and Organizational Antecedents, and the Role of Customer Engagement in Social Media. Ind. Mark. Manag. 2016, 54, 71-79. [CrossRef]

33. Andzulis, J.M.; Panagopoulos, N.G.; Rapp, A. A Review of Social Media and Implications for the Sales Process. J. Pers. Sell. Sales Manag. 2012, 32, 305-316. [CrossRef]

34. Kietzmann, J.H.; Hermkens, K.; McCarthy, I.P.; Silvestre, B.S. Social media? Get Serious! Understanding the Functional Building Blocks of Social Media. Bus. Horiz. 2011, 54, 241-251. [CrossRef]

35. Benevenuto, F.; Duarte, F.; Rodrigues, T.; Almeida, V.A.; Almeida, J.M.; Ross, K.W. Understanding Video Interactions in Youtube. In Proceedings of the 16th ACM International Conference on Multimedia, Vancouver, BC, Canada, 26-31 October 2008; ACM: New York, NY, USA, 2008; pp. 761-764.

36. Gallaugher, J.; Ransbotham, S. Social Media and Customer Dialog Management at Starbucks. MIS Q. Exec. $2010,9,197-212$.

37. Nielsen Company. State of the Media: The Social Media Report; Nielsen Company: New York, NY, USA, 2010.

38. Kumar, V.; Mirchandani, R. Increasing the ROI of Social Media Marketing. MIT Sloan Manag. Rev. 2012, 54, 55-61. [CrossRef]

39. Godey, B.; Manthiou, A.; Pederzoli, D.; Rokka, J.; Aiello, G.; Donvito, R.; Singh, R. Social Media Marketing Efforts of Luxury Brands: Influence on Brand Equity and Consumer Behavior. J. Bus. Res. 2016, 69, 5833-5841. [CrossRef]

40. Benevenuto, F.; Rodrigues, T.; Cha, M.; Almeida, V. Characterizing User Behavior in Online Social Networks. In Proceedings of the 9th ACM SIGCOMM Conference on Internet Measurement, Chicago, IL, USA, 4-6 November 2009; ACM: New York, NY, USA, 2009; pp. 49-62.

41. Preston, C.A. Event Marketing: How to Successfully Promote Events, Festivals, Conventions, and Expositions, 2nd ed.; Wiley: Hoboken, NJ, USA, 2012.

42. Bulearca, M.; Bulearca, S. Twitter: A Viable Marketing Tool for SMEs? Glob. Bus. Manag. Res. 2010, 2, 296.

43. Safko, L. The Social Media Bible: Tactics, Tools, and Strategies for Business Success; John Wiley \& Sons: Hoboken, NJ, USA, 2010.

44. Kwak, H.; Lee, C.; Park, H.; Moon, S. What is Twitter, a Social Network or a News Media? In Proceedings of the WWW '10: Proceedings of the 19th International Conference on World Wide Web, Raleigh, NC, USA, 26-30 April 2010; pp. 591-600. [CrossRef]

45. Engel, J.F.; Kollat, D.T.; Blackwell, R.D. Consumer Behavior; Holt, Rinehart \&Winston: New York, NY, USA, 1968.

46. Osei, B.A.; Abenyin, A.N. Applying the Engell-Kollat-Blackwell Model in Understanding International Tourists' Use of Social Media for Travel Decision to Ghana. Inf. Technol. Tour. 2016, 16, 265-284. [CrossRef]

47. Kim, S.; Lee, C. Push and Pull Relationships. Ann. Tour. Res. 2002, 29, 257-260. [CrossRef]

48. Snepenger, D.; King, J.; Marshall, E.; Uysal, M. Modeling Iso-Ahola's Motivation Theory in the Tourism Context. J. Travel Res. 2006, 45, 140-149. [CrossRef]

49. Maslow, A. Motivation and Personality; Harper \& Row: New York, NY, USA, 1954.

50. Plog, S. Why Destination Areas Rise and Fall in Popularity. Cornell Hotel Restaur. Adm. Q. 1974, 14, 55-58. [CrossRef]

51. Yoon, Y.; Uysal, M. An Examination of the Effects of Motivation and Satisfaction on Destination Loyalty: A Structural Model. Tour. Manag. 2005, 26, 45-56. [CrossRef]

52. Sohn, H.K.; Lee, T.J.; Yoon, Y. Relationship between Perceived Risk, Evaluation, Satisfaction, and Behavioral Intention: A Case of Local Festival Visitors. J. Travel Tour. Mark. 2016, 33, 28-45. [CrossRef]

53. Remenyi, D.; Williams, B.; Money, A.; Swartz, E. Doing Research in Business and Management: An Introduction to Process and Method; Sage: London, UK, 1998.

54. Saunders, M.; Lewis, P.; Thornhill, A. Research Methods for Business Students; Pearson Education: London, UK, 2009.

55. Ghauri, P.; Grønhaug, K. Research Methods in Business Studies; FT Prentice Hall: Harlow, UK, 2005.

56. Sekaran, U. Research Methods for Business: A Skill Building Approach; Wiley: Hoboken, NJ, USA, 2002. 